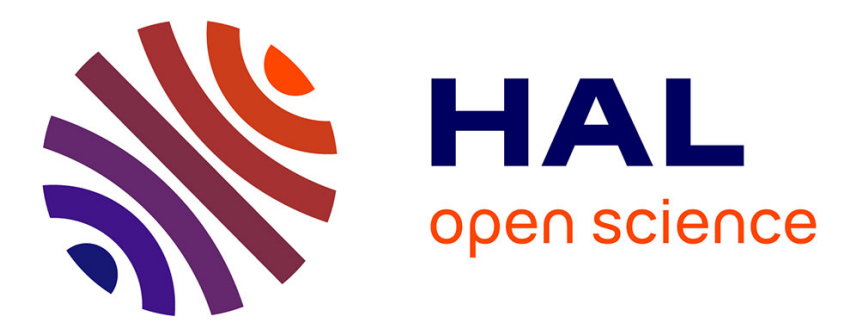

\title{
A Knowledge Engineering Perspective of Knowledge Management: How to Manage Project Meeting Knowledge
}

\author{
Jason Xinghang Dai, Nada Matta
}

\section{To cite this version:}

Jason Xinghang Dai, Nada Matta. A Knowledge Engineering Perspective of Knowledge Management: How to Manage Project Meeting Knowledge. 3rd IFIP International Workshop on Artificial Intelligence for Knowledge Management (AI4KM), Jul 2015, Buenos Aires, Argentina. pp.15-31, 10.1007/978-3-319-55970-4_2 . hal-01626989

\section{HAL Id: hal-01626989 \\ https://hal.inria.fr/hal-01626989}

Submitted on 31 Oct 2017

HAL is a multi-disciplinary open access archive for the deposit and dissemination of scientific research documents, whether they are published or not. The documents may come from teaching and research institutions in France or abroad, or from public or private research centers.
L'archive ouverte pluridisciplinaire $\mathbf{H A L}$, est destinée au dépôt et à la diffusion de documents scientifiques de niveau recherche, publiés ou non, émanant des établissements d'enseignement et de recherche français ou étrangers, des laboratoires publics ou privés. 


\title{
A Knowledge Engineering Perspective of Knowledge Management: How to Manage Project Meeting Knowledge
}

\author{
Xinghang DAI ${ }^{1}$, Nada MATTA ${ }^{2}$ \\ ${ }^{1}$ CTIT, University of Twente, Enschede, Netherlands \\ x.dai@utwente.nl \\ ${ }^{2}$ Tech-cico, University of Technology of Troyes, Troyes, France \\ nada.matta@utt.fr
}

\begin{abstract}
Knowledge management is a research topic that encompasses various domains. It is proved that both knowledge codification and social interaction can improve knowledge sharing in an organization, and IT has always been a powerful technology to support knowledge management cycle, especially on knowledge capturing, storage or even sharing. Knowledge engineering is an engineering science that represent knowledge into computable forms, in order to solve a problem in a specific domain, it offers useful approaches to obtain and model domain knowledge. In this paper, the knowledge produced in project meetings will be studied, and a semantic network based classification model will be proposed to support knowledge management, followed by two detailed case studies.
\end{abstract}

Keywords. Knowledge management, knowledge engineering, project, decisionmaking

\section{Introduction}

How to manage knowledge as an important social capital in an organization has always been a challenge since the knowledge economy shift [1]. Different approaches have been developed from different scientific perspectives. In general, these approaches fall into two categories: personalization approaches that emphasize social interactions among employees, and codification approaches that emphasize the knowledge storage and structuring [2][3]. Although both approaches have its pros and cons, they are not contradictory. Knowledge sharing is argued to be a social practice influenced by the dynamics of individuals, but ICT infrastructure stimulates, supports and facilitates knowledge sharing in an organization by providing favorable conditions [4]. Wilson and Snyder [5] argued that a knowledge management should pay attention to three aspects: information technology, people and process, and IT should player the major role in assisting people for knowledge creation, knowledge application. Therefore, the knowledge management strategy should not be isolated from the design of technic infrastructure of an organization, and IT should be incorporated within the knowledge 
management cycle. Knowledge engineering has always been a powerful technology to acquire and represent knowledge, and one of its main applications is expert system development. However current knowledge engineering research has shifted from mere expert knowledge extraction to a contextualized knowledge modeling embedded into a certain work process [6], [7].In order to adjust knowledge engineering methodologies to knowledge management, the goal should alter from representing knowledge in computable forms to presenting knowledge in a way that is valuable and easy for learning. In this paper, we try to tackle the knowledge management challenges from a knowledge engineering perspective, a classification framework will be proposed to structure project knowledge, and two case studies will be demonstrated.

\section{Related works}

Knowledge engineering is defined as the application of logic and ontology to the task of building computable models of some domain for some purpose [8], and most of the knowledge engineering approaches focus on how to capture domain knowledge from experts, documents or observations. The knowledge will be represented into formalized forms and computed into knowledge base. As for knowledge management, knowledge engineering methodologies provide explicit guidelines for knowledge codification, from knowledge capturing to knowledge retrieval. Some efforts have been done towards an integrated framework of knowledge engineering for knowledge management. They can be categorized into knowledge representation based approaches and knowledge classification based approaches. Knowledge representation based approaches focus on extracting and representing domain knowledge into computable formalizations, in order to build a knowledge base, capable of automatic reasoning and searching. Knowledge classification based approaches incline to use ontology or class hierarchy to classify knowledge, in order to facilitate knowledge sharing based on a shared understanding of terms.

Liebowitz [9] believes that knowledge management can be advanced by applying AI related technologies, such as knowledge acquisition, knowledge representation, data mining and text mining. Preece et al. [10] believe that knowledge engineering technology is significantly under-utilized for knowledge management, they applied knowledge engineering to a knowledge management system in the drill industry in two aspects: using knowledge acquisition processes to capture knowledge systematically and using knowledge representation to store knowledge in a structured manner. Maedche et al. [11] designed an ontology-based knowledge management system architecture, in which an ontology server is deployed. A mapping process is used to relate multiple ontologies, and ontology can evolve according to the current state of knowledge. Matta et al. [12] proposed a knowledge engineering based method called MASK to capitalize knowledge in an organization, it proposes to model knowledge in two dualities: flow/field and source/target. The MASK method extracts domain knowledge and represents it within the process of activity. Lai [13] defined a knowledge management through knowledge engineering (KMKE) framework, which involves knowledge modeling, knowledge verification, knowledge storage, knowledge querying and knowledge 
update. Conceptual graph is used to represent knowledge as well as its context. These examples of knowledge engineering based methods focus on how to capture knowledge and represent knowledge in a formalized way, however little efforts have been made to embedded this representation into the process of knowledge management. They tend to fall into the routine of expert system development, which neglects the knowledge sharing process. Moreover, one of the important challenges of knowledge engineering is how to properly model domain knowledge for problem-solving, hence the general framework needs to be elaborated in a specific domain.

\section{$3 \quad$ Knowledge and classification}

In the last two sections we argued that knowledge engineering methodologies can be used to improve knowledge management, however it is important to represent knowledge in a way that is easy for knowledge sharing. Knowledge representation based approaches are designed to develop expert systems, on the other hand, knowledge classification based approaches try to define the ontological structure of knowledge. In this section, the relation between classification and knowledge will be examined.

According to Statistics science, classification refers a process in which ideas and objects are recognized, differentiated, and understood [14]. Gordon [15] stated, "classification can be described as the activity of dividing a set of objects into a smaller number of classes in such a way that objects in the same class are similar to one another and dissimilar to objects in other classes ", he distinguished classification from, what he called, "assignment", which is the activity of allocating objects to one of a set of existing classes. And for cognitive science, classification is an important process to obtain knowledge, it is believed that data can be conceptualized into abstract hierarchized concepts in human mind, which is stocked in the long-term memory as structured, related networks [16], [17]. The mental model of classification is the meaningful clustering of experience; it contributes to accumulate knowledge and shapes it into a powerful representation [18]. Classification has different purposes in different stages, it can be used in a formative way as a heuristic tool during the preliminary stages of inquiry. Once concepts and relations among concepts become explicit, a classification can be used as a representation for communication or a medium for deeper knowledge generation. Hence two purposes of classification can be concluded:

- Hypothesis generation: in this phase, human experience is recognized, categorized to generate hypotheses; and this hypothesis can be reinforced by recurrence of the same experience or confirmed by relating to existing knowledge.

- Knowledge association: once the hypothesis accumulates for a period of time, it will be classified or associated into the structure of knowledge.

The quest for the balance of relativity and stability has shaped modern classification. While modern classification aims at representing the universe of knowledge, postmodern classification aims at providing a pragmatic tool for specific domains [19]. Knowledge engineering methodologies are good applications of classification. Hierarchical classification is always used to represent the ontological structure of concepts, 
while heuristic classification is used to represent problem solving methods, which entails direct association between concept [20], [21].

Knowledge engineering usually use knowledge modeling techniques to obtain knowledge by interviews with experts, document analysis, or observation, some predominant methodologies are CommonKADS [7], MIKE[22] and MASK[12]. Knowledge engineering methods are usually laborious, time-consuming and extremely domain specific. On the other hand, data-driven methods, such as text mining and data mining, try to find knowledge patterns from text and data [23][24]. These methods rely on a large volume of data and adequate prior domain knowledge. As for knowledge management, both perspectives are useful for knowledge explicitation and storage. Considering the learning aspect of knowledge management, it is crucial to relate abstract knowledge to specific practices, and knowledge needs to be embedded in the working process.

\section{$4 \quad$ Project meeting knowledge and CKD}

In the last section, we established the fact that classification techniques can be used to both knowledge discovery and knowledge representation. In this section, knowledge produced in project meetings will be studied, and a knowledge discovery framework will be introduced.

Nowadays, with the fast-paced innovation and increasing complexity of technology, project teams tend to be multi-disciplinary, which calls for a tighter collaboration between team member. Nonaka [25] and Spender [26] have emphasized that both individual knowledge and social knowledge exist in an organization. Individual knowledge is created and resides in individual's mind, whereas social knowledge is created by and inherent in the collective actions of a group. In a project meeting, on one hand each individual possesses expert knowledge; on the other hand, social knowledge is created by collaboration. We define this kind of social knowledge as cooperative knowledge, produced by the interactions among individuals in a group in cooperative work. Due to the collective and collaborative dimension of meetings, cooperative knowledge is different from expert knowledge for two reasons: 1). The domain context of knowledge is different. Expert knowledge is related to one field and contains routines and strategies developed individually from experiences, while cooperative knowledge is multidisciplinary 2). The social context of knowledge is different. Expert knowledge resides in individual's mind; its social context is that of its producer's. However, cooperative knowledge cannot be restricted to a single actor, the social context of cooperative knowledge is related to the whole group's dynamics [27].

In face of the particular features of project meeting knowledge, a cooperative knowledge discovery (CKD) framework has been defined [27]. The CKD framework emphasized that knowledge can be discovered from a structured project traceability (Fig.1.). It consists of three layers: information layer, where project information is captured in a structured manner; model layer, where models are designed according to different types of knowledge in a specific domain; knowledge layer, where model instances will be generalized into abstract rules. In the case of project meeting knowledge, 
it proposed faceted classification models on decision-making, project organization, project realization, and project planning.

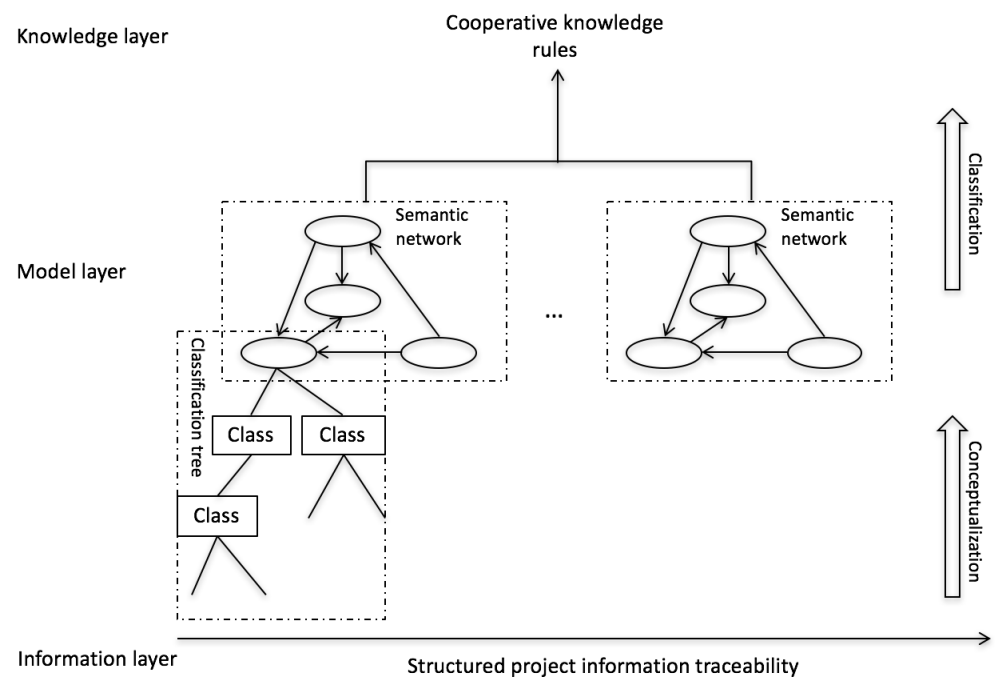

Fig. 1. The CKD framework

In the context of project meetings, two classification models have been defined so far.

\subsection{Problem-solving}

This model focuses purely on how a problem is resolved through discussion. The decision-making process is usually intrigued by an issue, and finished by reaching a decision. It should be a dynamic information exchange from different elements, namely the negotiation process, as well as argumentations (Fig.2.). The concepts we identified in the decision-making model are:

- Issue: the question or the problem that we need to discuss in the decision-making, it can be a question on design concept, a problem encountered during project realization, or a management issue etc.

- Proposition: alternative solutions for the issue. Propositions can also evolve during a decision-making.

- Argument: reasons to criticize or support a proposition. If necessary, argument can also aim at issue, which can reform the issue.

- Decision: the agreement on a solution for the issue. A decision can be made in the end based on an evaluation of propositions. 




Fig. 2. Problem-solving model

Model instances with the similar "Issue" will be classified together. The similar decisions will be classified directly as the "essential solutions" for the issue; similar propositions that are not included in decisions will be classified as "conditional solutions"; unique propositions that are excluded from decisions will be classified as explorative solutions. For each proposition, arguments from all the instances will be presented. And a weight factor will be introduced to represent the importance of the concept.

\subsection{Project organization}

How decisions are made is valuable knowledge, but who are involved, and how they behave in decision-making is very important knowledge from a manager's point of view (Fig.3.). And four concepts are defined to represent social context:

- Actor: the participant of a project.

- Competence: skills possessed by an actor.

- Role: the position of an actor in a project (e.g. manager, designer etc.).

- Organizational state: the state of an actor's organizational commitment (e.g. company employee, third party consultant or freelance designer etc.)

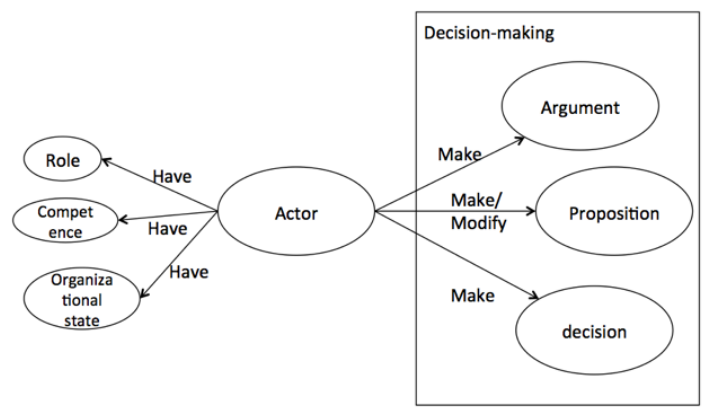

Fig. 3. Project organization 
Competence, role and organizational state can be viewed as properties of an actor, and actor is the concept that connects social context with decision-making.

By classifying instances of this model, we can establish connections between an actor's properties (role, competence and organizational state) with how one makes proposition, argument and decision.

\section{$5 \quad$ Case studies}

In this section, two detailed case studies will be demonstrated to show the plausibility of CKD framework for knowledge management. The tablet application MMrecord and MMreport [28] are used to capture the project meeting traceability in each project.

\subsection{Software design}

This case study consists of two software design projects, undertaken by two different groups of Master students of University of Technology of Troyes in the year 2012 and 2013. The group members consist of students majoring in computer science and students majoring in mechanical design. The project 2012 involves eight students, among whom four major in computer science and 4 in mechanical design, and for project 2013, 5 students participated, 3 of them major in computer science and 2 major in mechanical design. The goal of this project is to design a tablet application, which aids a mechanical technician in product maintenance. An evaluation of project result shows that the first project failed because it does not respect the project budget, and the second one succeeded to meet all the project specifications. We collected the recording of their work meetings from MMreport and their project report. After analysing the project traceability, two classification models are identified, problem-solving and project organization.

\section{Problem-solving knowledge.}

One similar issue that both groups tackled in their projects is to define the function of this application. The decision-making process of both groups on this issue are put in tables as follows (table 1):

Table 1 Decision-making on the issue "function definition" of project 2012 and project 2013

\begin{tabular}{|c|c|c|c|}
\hline \multicolumn{4}{|c|}{ Project 2012 Tablet application for product maintenance, issue: function definition } \\
\hline Proposition & \multicolumn{2}{|c|}{ Argument } & Decision \\
\hline \multirow{4}{*}{$\begin{array}{l}\text { Automatic object recog- } \\
\text { nition by image to detect } \\
\text { product }\end{array}$} & \multirow[t]{2}{*}{ defend } & Improve efficiency & \multirow{3}{*}{$\begin{array}{l}\text { Automatic object } \\
\text { recognition by image }\end{array}$} \\
\hline & & Easy access & \\
\hline & \multirow[t]{2}{*}{ criticize } & Increase budget & \\
\hline & & Complex development & \multirow{4}{*}{$\begin{array}{l}\text { Four databases } \\
\text { Information } \\
\text { change between the }\end{array}$} \\
\hline \multirow{3}{*}{$\begin{array}{l}\text { Single database for all } \\
\text { modules }\end{array}$} & \multirow[t]{2}{*}{ criticize } & Need data synchronization & \\
\hline & & Create data redundancy & \\
\hline & defend & Easy administration & \\
\hline
\end{tabular}




\begin{tabular}{l|l|l|l}
\hline $\begin{array}{l}\text { Four databases, one for } \\
\text { each module }\end{array}$ & Null & \multirow{2}{*}{$\begin{array}{l}\text { application and ERP, } \\
\text { PLM }\end{array}$} \\
\hline $\begin{array}{l}\text { Information exchange be- } \\
\text { tween ERP and PLM }\end{array}$ & defend & Reduce data redundancy & \\
\cline { 2 - 3 } $\begin{array}{l}\text { Information exchange be- } \\
\text { tween the application and }\end{array}$ & Null & Technological obstacle & \\
ERP, PLM & & \\
\hline
\end{tabular}

Project 2013 Tablet application for product maintenance, issue: function definition

\begin{tabular}{|c|c|c|c|}
\hline Proposition & \multicolumn{2}{|c|}{ Argument } & Decision \\
\hline \multirow{2}{*}{$\begin{array}{l}\text { Manuel search for con- } \\
\text { cerning knowledge for } \\
\text { problem }\end{array}$} & defend & Easy implementation & \multirow{5}{*}{$\begin{array}{l}\text { Manuel search for } \\
\text { knowledge of con- } \\
\text { cerning product } \\
\text { Single database } \\
\text { Information ex- } \\
\text { change between the } \\
\text { application and ERP, } \\
\text { PLM }\end{array}$} \\
\hline & criticize & $\begin{array}{l}\text { Requires users to have certain } \\
\text { mechanical knowledge }\end{array}$ & \\
\hline \multirow[t]{3}{*}{$\begin{array}{l}\text { Single database for all } \\
\text { modules }\end{array}$} & \multirow[t]{3}{*}{ defend } & $\begin{array}{l}\text { Centralized administration } \\
\text { improve searching }\end{array}$ & \\
\hline & & $\begin{array}{l}\text { Secure information confiden- } \\
\text { tiality }\end{array}$ & \\
\hline & & $\begin{array}{l}\text { Evade frequent communica- } \\
\text { tion among the modules }\end{array}$ & \\
\hline $\begin{array}{l}\text { Information exchange be- } \\
\text { tween the application and } \\
\text { ERP, PLM }\end{array}$ & \multicolumn{2}{|r|}{ 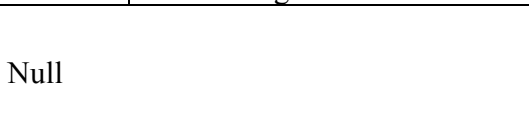 } & \\
\hline
\end{tabular}

With the same project specification, on the same issue "function definition", decisionmaking produces different outcomes. According to the classification rule, similar decisions will be classified as essential solutions; similar propositions that are excluded from essential decisions will be classified as conditional solutions; unique propositions will be classified as explorative solutions. Arguments will be combined and attached to decisions and propositions as explanation. And a weight factor $\mathrm{W}_{\mathrm{i}}$ will be attached to each concept to indicate its importance, this factor increases by one each time a similar instance is classified. The classification result in shown in table 2 .

Table 2 Classification result of the issue "function definition"

\begin{tabular}{l|l|l|l}
\hline \multicolumn{2}{l|}{ Project of tablet application design for product maintenance Issue: function definition } \\
\hline Essential solutions & $\begin{array}{l}\text { Information exchange be- } \\
\text { tween the application and } \\
\text { ERP, PLM }\left(\mathrm{W}_{1}=1\right)\end{array}$ & Null \\
\hline $\begin{array}{l}\text { Conditional solu- } \\
\text { tions }\end{array}$ & $\begin{array}{l}\text { Automatic object recogni- } \\
\text { tion by image }\left(\mathrm{W}_{2}=0\right)\end{array}$ & defend & Improve efficiency $\left(\mathrm{W}_{21}=0\right)$ \\
\cline { 3 - 4 } & & criticize & \begin{tabular}{l} 
Easy access $\left(\mathrm{W}_{22}=0\right)$ \\
\cline { 3 - 4 }
\end{tabular} \\
\cline { 3 - 4 } & & $\begin{array}{l}\text { Increase budget }\left(\mathrm{W}_{23}=0\right) \\
\text { Complex } \\
\left(\mathrm{W}_{24}=0\right)\end{array}$ \\
\hline
\end{tabular}




\begin{tabular}{|c|c|c|c|}
\hline & $\begin{array}{l}\text { Manuel search for concern- } \\
\text { ing knowledge for problem } \\
\left(\mathrm{W}_{3}=0\right)\end{array}$ & criticize & $\begin{array}{l}\text { Requires users to have certain } \\
\text { mechanical knowledge } \\
\left(\mathrm{W}_{32}=0\right)\end{array}$ \\
\hline & \multirow[t]{5}{*}{$\begin{array}{l}\text { Single database for all mod- } \\
\text { ules }\left(\mathrm{W}_{4}=1\right)\end{array}$} & \multirow[t]{3}{*}{ defend } & $\begin{array}{l}\text { Centralized administration } \\
\text { improve searching }\left(\mathrm{W}_{41}=1\right)\end{array}$ \\
\hline & & & $\begin{array}{l}\text { Secure information confiden- } \\
\text { tiality }\left(\mathrm{W}_{42}=1\right)\end{array}$ \\
\hline & & & $\begin{array}{l}\text { Evade frequent communica- } \\
\text { tion among the modules } \\
\left(\mathrm{W}_{43}=1\right)\end{array}$ \\
\hline & & \multirow[t]{2}{*}{ criticize } & $\begin{array}{l}\text { Need data synchronization } \\
\left(\mathrm{W}_{44}=1\right)\end{array}$ \\
\hline & & & $\begin{array}{l}\text { Create data redundancy } \\
\left(\mathrm{W}_{44}=1\right)\end{array}$ \\
\hline & $\begin{array}{l}\text { Four databases, one for } \\
\text { each module }\left(W_{5}=0\right)\end{array}$ & \multicolumn{2}{|l|}{ Null } \\
\hline \multirow[t]{2}{*}{$\begin{array}{l}\text { Explorative solu- } \\
\text { tions }\end{array}$} & \multirow{2}{*}{$\begin{array}{l}\text { Information exchange be- } \\
\text { tween ERP and PLM } \\
\left(\mathrm{W}_{6}=0\right)\end{array}$} & defend & $\begin{array}{lll}\text { Reduce } & \text { data } & \text { redundancy } \\
\left(\mathrm{W}_{61}=0\right) & & \\
\end{array}$ \\
\hline & & criticize & $\begin{array}{l}\text { Technological } \\
\left(\mathrm{W}_{62}=0\right)\end{array}$ \\
\hline
\end{tabular}

In the classification result, we can see that the similar decision "the connection between the application and ERP, PLM" is classified as the essential solution for the issue "function definition". The other similar propositions are about two aspects: the search function and database design, they are regarded as conditional solutions. One proposition is unique, "connection between PLM and ERP", it is put aside as explorative solution for future classification. Conditional solutions are solutions we need to consider with respect to their risks. For example, the conditional solution "automatic object recognition by image" is the reason why the first project failed to satisfy the project budget, but in another project, with a more generous budget, this solution might be very useful. The classification result of the problem solving process on this issue may improve the decision-making for another similar situation.

\section{Project organization.}

The management knowledge tries to reveal the social influence on decision-making and project realization. Here we want to examine how competences of actors influence their behaviours in the decision-making process above. In both of the projects, they choose the same organization divisions according to three functions: ERP, PLM and Tablet application. However, in each group, the competence distribution is not different. We define the logic predicate ( $\mathrm{Ar}_{\mathrm{i} j}$, competence, organizational_division) to represent the actors and their properties. This model instance can be written in a table as follows in table 3.

Table 3. decision-making on the issue "function definition" with social context 


\begin{tabular}{|c|c|c|c|}
\hline \multirow{5}{*}{$\begin{array}{l}\text { Proposition } \\
\text { Automatic object } \\
\text { recognition by } \\
\text { image to detect } \\
\text { product }\left[A r_{I 2,}\right. \\
\text { Computer_sci- } \\
\text { ence, } \\
\text { APP_division] }\end{array}$} & \multicolumn{2}{|c|}{ Argument } & \multirow{3}{*}{$\begin{array}{l}\text { Decision } \\
\text { Automatic object } \\
\text { recognition by image } \\
\text { [Ar }{ }_{12}, \text { Computer_sci- } \\
\text { ence, APP_division] }\end{array}$} \\
\hline & \multirow[t]{2}{*}{ defend } & $\begin{array}{l}\text { Improve efficiency }\left[\mathrm{Ar}_{11}, \mathrm{Com}-\right. \\
\text { puter science, } A P P \text { division] }\end{array}$ & \\
\hline & & $\begin{array}{l}\text { Easy access [Ar } r_{11} \text {,Computer_sci- } \\
\text { ence,APP_division] }\end{array}$ & \\
\hline & \multirow[t]{2}{*}{ criticize } & $\begin{array}{l}\text { Increase budget [Ar }{ }_{15}, \text { Mechani- } \\
\text { cal_design,ERP_division] }\end{array}$ & \multirow{9}{*}{$\begin{array}{l}\text { Four databases } \\
{\left[\text { Ar }_{11}, \text { Computer_sci- }\right.} \\
\text { ence,APP_division] } \\
\text { Information exchange } \\
\text { between the applica- } \\
\text { tion and ERP, PLM } \\
\text { [Ar }{ }_{16}, \text { Mechanical_de- } \\
\text { sign,ERP_division] }\end{array}$} \\
\hline & & $\begin{array}{l}\text { Complex development }\left[\mathrm{Ar}_{15}, \mathrm{Me}-\right. \\
\text { chanical design,ERP division] }\end{array}$ & \\
\hline \multirow{3}{*}{$\begin{array}{l}\text { Single database } \\
\text { for all modules } \\
{\left[\mathrm{Ar}_{13}, \mathrm{Com} \text { - }\right.} \\
\text { puter_sci- } \\
\text { ence,APP_divisi } \\
\text { on] }\end{array}$} & \multirow[t]{2}{*}{ criticize } & $\begin{array}{l}\text { Need data synchronization [Ar }{ }_{12} \text {, } \\
\text { Computer science, } A P P \text { division] }\end{array}$ & \\
\hline & & $\begin{array}{l}\text { Create data redundancy }\left[A r_{12}, C o m-\right. \\
\text { puter science, } A P P \text { division] }\end{array}$ & \\
\hline & defend & $\begin{array}{l}\text { Easy administration }\left[A r_{13}, \mathrm{Com}-\right. \\
\text { puter science, } A P P \text { division] }\end{array}$ & \\
\hline $\begin{array}{l}\text { Four databases, } \\
\text { one for each } \\
\text { module } \\
\text { [Ar }{ }_{11}, \text { Com- } \\
\text { puter_sci- } \\
\text { ence,APP_divisi } \\
\text { on] }\end{array}$ & \multicolumn{2}{|l|}{ Null } & \\
\hline \multirow{2}{*}{$\begin{array}{l}\text { Information ex- } \\
\text { change between } \\
\text { ERP and PLM } \\
{\left[A r_{16}, \text { Mechani- }\right.} \\
\text { cal_de- } \\
\text { sign,ERP_divisio } \\
n]\end{array}$} & defend & $\begin{array}{l}\text { Reduce data redundancy [Ar }{ }_{16}, M e- \\
\text { chanical_design,ERP_division] }\end{array}$ & \\
\hline & criticize & $\begin{array}{l}\text { Technological obstacle [Ar }{ }_{14}, \mathrm{Com}- \\
\text { puter_science,APP_division] }\end{array}$ & \\
\hline $\begin{array}{l}\text { Information ex- } \\
\text { change between } \\
\text { the application } \\
\text { and ERP, PLM } \\
{\left[A r_{17}, \text { Mechani- }\right.} \\
\text { cal_de- } \\
\text { sign,PLM_divisi } \\
\text { on] [Ar } r_{15}, M e- \\
\text { chanical_de- } \\
\text { sign,ERP_divisio } \\
n]\left[A r_{16}, \text { Mechan- }\right. \\
\text { ical_de- } \\
\text { sign,ERP_divisio } \\
n]\end{array}$ & \multicolumn{2}{|l|}{ Null } & \\
\hline
\end{tabular}

Project 2013 on tablet application for product maintenance, issue: function definition 


\begin{tabular}{|c|c|c|c|}
\hline Proposition & Argume & & Decision \\
\hline \multirow{2}{*}{$\begin{array}{l}\text { Manuel search } \\
\text { for concerning } \\
\text { knowledge for } \\
\text { problem } \\
{\left[\text { Ar }_{21}, C_{\text {Com- }}\right.} \\
\text { puter_sci- } \\
\text { ence,APP_divisi } \\
\text { on] }\end{array}$} & defend & $\begin{array}{l}\text { Easy implementation }\left[\mathrm{Ar}_{23}, \mathrm{Com}-\right. \\
\text { puter_science, ERP_division] }\end{array}$ & \multirow{6}{*}{ 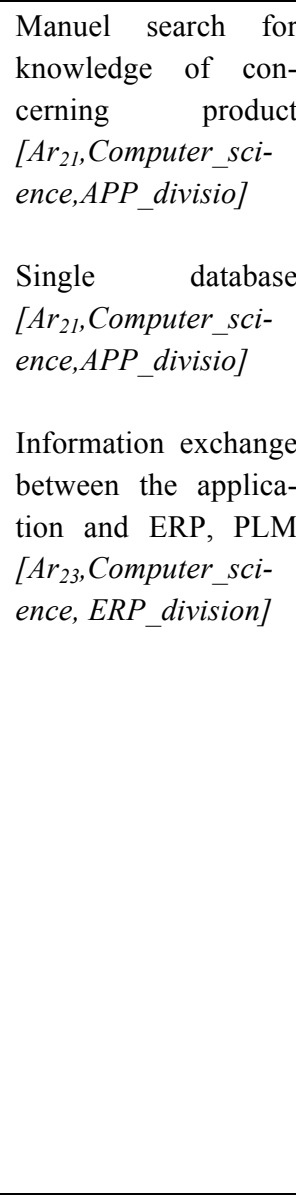 } \\
\hline & criticize & $\begin{array}{l}\text { Requires users to have certain me- } \\
\text { chanical knowledge }\left[\mathrm{Ar}_{24}, \text { Mechani- }\right. \\
\text { cal_design, APP_division] }\end{array}$ & \\
\hline \multirow{3}{*}{$\begin{array}{l}\text { Single database } \\
\text { for all modules } \\
{\left[\mathrm{Ar}_{21}, \mathrm{Com} \text { - }\right.} \\
\text { puter_sci- } \\
\text { ence,APP_divisi } \\
\text { o] }\end{array}$} & \multirow[t]{3}{*}{ defend } & $\begin{array}{l}\text { Centralized administration improve } \\
\text { searching }\left[\mathrm{Ar}_{21} \text {,Computer_sci- }\right. \\
\text { ence,APP_divisio] }\end{array}$ & \\
\hline & & $\begin{array}{l}\text { Secure information confidentiality } \\
{\left[A r_{25}, \quad M e c h a n i c a l \text { design, }\right.} \\
P L M \text { division] }\end{array}$ & \\
\hline & & $\begin{array}{l}\text { Evade frequent communication } \\
\text { among the modules [Ar }{ }_{22}, \text { Com- } \\
\text { puter_science, PLM_division] }\end{array}$ & \\
\hline $\begin{array}{l}\text { Information ex- } \\
\text { change between } \\
\text { the application } \\
\text { and ERP, PLM } \\
\text { [Ar }{ }_{22}, \text { Com- } \\
\text { puter_science, } \\
\text { PLM_division] } \\
\text { [Ar }{ }_{23}, \text { Com- } \\
\text { puter_science, } \\
\text { ERP_division] }\end{array}$ & \multicolumn{2}{|l|}{ Null } & \\
\hline
\end{tabular}

By comparing these two model instances, we can relate actor's competence with different types of proposition or argument. Actors with competence computer science make all the IT implementation propositions; all the usability-oriented arguments are from actors with competence mechanical design; decisions about a specific function are made by actors within the organizational division on the same function. We note especially for the proposition "automatic object recognition by image to detect product", it is made by Actor 12 with computer science background, in the tablet application development division. Another actor with mechanical design background from the ERP division criticizes this proposition, but this proposition is still taken as decision, which leads the project failed by exceeding the project budget. But in another project, a more balanced proposition "manual research pertinent knowledge" was made by the actor from tablet application development division, which meets the project specification within project budget. We may assume that the variety of competences in a group can push ideas form different points of view to confront each other, which may lead to a balanced solution. 


\section{Case Analysis.}

In this case study, students followed our indications to keep track of their project. So, we succeeded to build links between collaborative decision-making and project organization. We applied two classification rules: problem solving rule that points out essential solutions and conditional solutions for a problem, and project organization rule that shows organizational influences on decision-making. The weight factor is a useful indicator to show the importance of each element. More importantly, the arguments are classified and attached to solutions, which explain the advantages, disadvantages or conditions for the solutions. The classification of decision-making in social context enables us to learn how organization influences decision-making. In this case, management classification shows that multi-disciplinary organization inclines to engage into cooperative work, designing a relatively balanced solution that responds to most of project goals.

\subsection{System design}

This example involves three student projects in year 2014. Two groups of students majoring in mechanical design were asked to design a PLM system for a company named IRobot. The software Windchill is supposed to be used as the PLM system, but it were the students to decide how to implement this system in light of the company's situation. The organization of IRobot can be divided into internal actors and external actors. Internal organizational consists of a hierarchy of CEO, director of managers, managers of product, and then engineers and technicians who form a work team for each client. External actors are suppliers and clients. The need of the company is to improve the information exchange between actors in a project and enhance reutilization of standard components between different types of products.

\section{Problem-solving knowledge.}

After analysing the recording of MMreport and their reports, one similar issue "general solution of PLM" is identified for this example. In this scenario, two project groups try to define the general solutions of PLM system, as shown in table 4.

Table 4. Problem-solving process of the issue "general solution for PLM"

Project of PLM system design of group 1, issue: search for general solutions for PLM

\begin{tabular}{l|l|l|l|}
\hline Proposition & \multicolumn{2}{|l|}{ Argument } & Decision \\
\hline $\begin{array}{l}\text { Change the or- } \\
\text { ganization of } \\
\text { company }\end{array}$ & Defend & $\begin{array}{l}\text { All possible solutions need to be } \\
\text { proposed }\end{array}$ & $\begin{array}{l}\text { Implementation } \\
\text { Windchill }\end{array}$ \\
& $\begin{array}{l}\text { Company's organization have to } \\
\text { be the same as PLM system }\end{array}$ & \\
\cline { 2 - 3 } & Criticize & $\begin{array}{l}\text { The PLM system allows to assign } \\
\text { different roles in the system }\end{array}$ & \multicolumn{1}{|c|}{$\begin{array}{l}\text { PLM solution need to focus on } \\
\text { technical aspect but not organiza- } \\
\text { tion }\end{array}$} \\
\hline
\end{tabular}




\begin{tabular}{|c|c|c|c|}
\hline $\begin{array}{l}\text { Implementation } \\
\text { of Windchill }\end{array}$ & \multicolumn{2}{|l|}{ Null } & \\
\hline \multicolumn{4}{|c|}{ Project of PLM system design of group 2, issue: search for general solutions for PLM } \\
\hline Proposition & \multicolumn{2}{|c|}{ Argument } & Decision \\
\hline \multirow{3}{*}{$\begin{array}{l}\text { Change the or- } \\
\text { ganization of the } \\
\text { company from } \\
\text { client oriented to } \\
\text { product oriented }\end{array}$} & \multirow[t]{2}{*}{ Defend } & $\begin{array}{l}\text { Product oriented organization is } \\
\text { more compatible with PLM }\end{array}$ & \multirow{3}{*}{$\begin{array}{l}\text { Change the organization } \\
\text { of the company from } \\
\text { client oriented to prod- } \\
\text { uct oriented }\end{array}$} \\
\hline & & $\begin{array}{l}\text { The work mode of the company } \\
\text { need to change in order to reduce }\end{array}$ & \\
\hline & Criticize & $\begin{array}{l}\text { Company needs long time to ad- } \\
\text { just to new organization change }\end{array}$ & \\
\hline $\begin{array}{l}\text { Implementation } \\
\text { of Windchill }\end{array}$ & \multicolumn{2}{|l|}{ Null } & $\begin{array}{l}\text { Implementation of } \\
\text { Windchill }\end{array}$ \\
\hline
\end{tabular}

By classifying these two model instances, we can obtain a problem-solving knowledge on the issue "PLM system general solution design". By classifying the decisions in both projects, we conclude that the implementation of Windchill is an essential solution for this issue. The classification of propositions results in a conditional solution: change company's organization into product-oriented organization, for this proposition, both groups have the same positive argument "company's organization should adjust to PLM system", thus the weight factor for this argument is 1 to indicate that this is an important reason (table 5.).

Table 5. Classification result of problem-solving knowledge on the issue "general solution"

\begin{tabular}{|c|c|c|c|}
\hline \multicolumn{4}{|c|}{ Project of PLM system design, issue: search for general solutions for PLM } \\
\hline & & \multicolumn{2}{|c|}{ Argument } \\
\hline $\begin{array}{l}\text { Essential solu- } \\
\text { tions }\end{array}$ & $\begin{array}{l}\text { Implementation of } \\
\text { Windchill }\left(\mathrm{W}_{1}=1\right)\end{array}$ & \multicolumn{2}{|l|}{ Null } \\
\hline \multirow[t]{6}{*}{$\begin{array}{l}\text { Conditional } \\
\text { solutions }\end{array}$} & \multirow{6}{*}{$\begin{array}{l}\text { Change company's } \\
\text { organization into } \\
\text { product-oriented or- } \\
\text { ganization. }\left(\mathrm{W}_{2}=1\right)\end{array}$} & \multirow[t]{3}{*}{ Defend } & $\begin{array}{l}\text { All possible solution needs to be pro- } \\
\text { posed }\left(\mathrm{W}_{21}=0\right)\end{array}$ \\
\hline & & & $\begin{array}{l}\text { Work mode need to change com- } \\
\text { pletely in the face of fluctuant client } \\
\text { demand }\left(\mathrm{W}_{22}=0\right)\end{array}$ \\
\hline & & & $\begin{array}{l}\text { Company's organization should be } \\
\text { adjusted to PLM system }\left(\mathrm{W}_{23}=1\right)\end{array}$ \\
\hline & & \multirow[t]{3}{*}{ Criticize } & $\begin{array}{l}\text { The company needs long time to ad- } \\
\text { just to organization changes }\left(\mathrm{W}_{24}=0\right)\end{array}$ \\
\hline & & & $\begin{array}{l}\text { PLM system allows to assign roles in } \\
\text { the system }\left(\mathrm{W}_{25}=0\right)\end{array}$ \\
\hline & & & $\begin{array}{l}\text { PLM solution need to focus on tech- } \\
\text { nical solutions }\left(\mathrm{W}_{26}=0\right)\end{array}$ \\
\hline
\end{tabular}

Both groups of students major in mechanical system for the diploma of engineer in France. Though their competences are the same, but the decisions they made are different. Next, we want to examine from the perspective of organization the reason why the decisions are different. 


\section{Project organization.}

Two groups of students are supposed to have the same competences, but their decisions on the same issue are different. We want to put the decision-making process in its social context to examine the social influence on decision-making. There are five actors in group 1, no team leader is named. Four of them are full-time students, following the same course in the same class in University of Technology of Troyes (UTT); one of them follows the sandwich course, and during the project, he is working in a company exterior of UTT. There are six actors in group 2, no team leader is named. One of them follows the sandwich course, working in a company during the project; the rest of them are full-time students in UTT. The comparison of project organization can be put into the table 6.

Table 6. Decision-making in social context model instance on the issue "PLM general solution

Project of PLM system design of group 1, issue: search for general solutions for PLM

\begin{tabular}{|c|c|c|c|}
\hline Proposition & \multicolumn{2}{|c|}{ Argument } & Decision \\
\hline \multirow{4}{*}{$\begin{array}{l}\text { Change the organization } \\
\text { of company }\left[A r_{15}, \mathrm{Me}-\right. \\
\text { chanical_system, Exte- } \\
\text { rior_UTT] }\end{array}$} & \multirow[t]{2}{*}{ Defend } & $\begin{array}{l}\text { All possible solutions need to be } \\
\text { proposed }\left[A r_{15} \text {, Mechanical_system, }\right. \\
\text { Exterior_UTT] }\end{array}$ & \multirow{5}{*}{$\begin{array}{l}\text { Implemen- } \\
\text { tation of } \\
\text { Windchill } \\
{\left[A r_{12}, \quad M e-\right.} \\
\text { chani- } \\
\text { cal_system, } \\
\text { Inte- } \\
\text { rior_UTT] }\end{array}$} \\
\hline & & $\begin{array}{l}\text { Company's organization have to be } \\
\text { the same as PLM system }\left[\mathrm{Ar}_{13}, \mathrm{Me} \text { - }\right. \\
\text { chanical_system, Interior_UTT] }\end{array}$ & \\
\hline & \multirow[t]{2}{*}{ Criticize } & $\begin{array}{l}\text { The PLM system allows to assign } \\
\text { different roles in the system }\left[A r_{12} \text {, }\right. \\
\text { Mechanical system, Interior UTT] }\end{array}$ & \\
\hline & & $\begin{array}{l}\text { PLM solution need to focus on tech- } \\
\text { nical aspect but not organization } \\
{\left[A r_{12} \text {, Mechanical_system, Inte- }\right.} \\
\text { rior_UTT] }\end{array}$ & \\
\hline $\begin{array}{l}\text { Implementation of Wind- } \\
\text { chill } \\
{\left[\text { Ar }_{12}, \text { Mechanical_sys- }\right.} \\
\text { tem, Interior_UTT] [Ar }{ }_{11} \text {, } \\
\text { Mechanical_system, Inte- } \\
\text { rior_UTT] }\end{array}$ & \multicolumn{2}{|l|}{ Null } & \\
\hline
\end{tabular}

Project of PLM system design of group 2, issue: search for general solutions for PLM

\begin{tabular}{|c|c|c|c|}
\hline Proposition & Argume & & Decision \\
\hline \multirow{2}{*}{$\begin{array}{l}\text { Change the organization } \\
\text { of the company from cli- } \\
\text { ent oriented to product ori- } \\
\text { ented [Ar } 22, \text { Mechani- } \\
\text { cal_system, } \\
\text { rior_UTT] Inte- }\end{array}$} & \multirow[t]{2}{*}{ Defend } & $\begin{array}{l}\text { Product oriented organization is } \\
\text { more compatible with PLM }\left[A r_{22} \text {, }\right. \\
\text { Mechanical system, Interior_UTT] }\end{array}$ & \multirow{2}{*}{$\begin{array}{l}\text { Change the } \\
\text { organization } \\
\text { of the com- } \\
\text { pany from } \\
\text { client ori- } \\
\text { ented to } \\
\text { product ori- } \\
\text { ented }\left[A r_{24} \text {, }\right.\end{array}$} \\
\hline & & $\begin{array}{l}\text { The work mode of the company } \\
\text { need to change in order to reduce } \\
{\left[A r_{22}, \text { Mechanical_system, Inte- }\right.} \\
\text { rior_UTT] [Ar } r_{23} \text {, Mechanical_sys- } \\
\text { tem, Interior_UTT] }\end{array}$ & \\
\hline
\end{tabular}




\begin{tabular}{|c|c|c|c|}
\hline & Criticize & $\begin{array}{l}\text { Company needs long time to adjust } \\
\text { to new organization change }\left[A r_{24} \text {, }\right. \\
\text { Mechanical_system, Interior_UTT] }\end{array}$ & $\begin{array}{l}\text { Mechani- } \\
\text { cal_system, } \\
\text { Inte- } \\
\text { rior UTT] }\end{array}$ \\
\hline $\begin{array}{l}\text { Implementation of Wind- } \\
\text { chill_ }\left[A r_{22},\right. \\
\text { cal_system, Mechani- } \\
\text { rior_UTT] }\left[A r_{24}, \text { Mechan- }\right. \\
\text { ical_system, } \\
\text { rior_UTT] }\left[\text { Ar }_{26}, \text { Mechan- }\right. \\
\text { ical_system, } \\
\text { rior_UTT] }\end{array}$ & Null & & 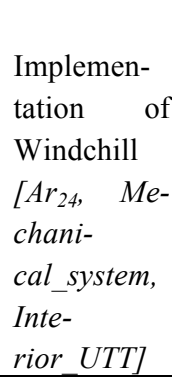 \\
\hline
\end{tabular}

We can see in the first model instance, the proposition "change the company's organization" is proposed by an actor exterior of UTT (he participated the meeting by Skype), and his proposition is ignored during the decision. As in the second group, the same proposition is proposed by an actor interior of UTT, and his proposition is included in the decision. We may draw the hypothesis that the actor's organizational state may influence the decision-making: actors who are physically exterior of organization tends to be less important than actors who are physically present in a decision making process. This hypothesis can be tested in the similar situations in the future.

\section{Case analysis.}

Two student projects on PLM system design are analysed. Although they are asked to use the same software Windchill to implement the PLM system, but the decisions of the two groups are not the same. By examining the negotiation process, we see that both groups propose the solution to change the company's organization, but only one group take this proposition into consideration. All the students have the same competence: mechanical system, but different organizational sate. Some of them are interior UTT, and they are physically present for meetings; some of them are in company, and they participated meetings via Skype. The classification result of decision-making in social context model makes us draw the hypothesis that the influence of actors who are physically present in a meeting is stronger than those who doesn't.

\section{Discussion}

The two case studies that are presented above are preliminary applications of the CKD framework. The problem-solving knowledge of each case is valid experience generalization, however, with the accumulation of project experience, a class hierarchy with an appropriate granularity needs to be built to conceptualize information into concepts. In both project examples, the group members are required to hold their meetings in a controlled manner, which follows a classic decision-making process. The project organization knowledge only examines the competence, role and organizational state in these two examples, but we are aware that the social context of a project meeting is far more 
complicated in practice. This research needs to completed by a larger and richer dataset study.

\section{Conclusion}

In this paper, we argued that knowledge engineering methodologies can be used to improve knowledge management. The goal of knowledge engineering needs to shift from developing expert systems to represent knowledge in a way that is easy for knowledge sharing, and it needs to be embedded in the cycle of knowledge management. The CKD framework is introduced and two case studies are demonstrated. In the future, this framework will be elaborated in another domain with more data sets.

\section{References}

[1] T. A. Stewart, "Brainpower," Fortune, vol. 123, no. 11, pp. 44-60, 1991.

[2] C. McMahon, A. Lowe, and S. Culley, "Knowledge management in engineering design: personalization and codification," J. Eng. Des., vol. 15, no. 4, pp. 307-325, 2004.

[3] M. T. Hansen, N. Nohria, and T. Tierney, "What's your strategy for managing knowledge?," Harv. Bus. Rev., vol. 77, no. 2, pp. 106-116, 1999.

[4] M. Alavi and D. E. Leidner, "and Management Review : Knowledge Systems : Management Knowledge and Foundations Conceptual," MIS Q. vol. 25 , no. 1, pp. 107-136, 2011.

[5] L. T. Wilson and C. A. Snyder, "Knowledge management and IT: how are they related," IT Prof., vol. 1, no. 2, pp. 73-75, 1999.

[6] R. Studer, V. R. Benjamins, and D. Fensel, "Knowledge engineering: Principles and methods," Data Knowl. Eng., vol. 25, no. 1-2, pp. 161-197, 1998.

[7] H. Akkermans, B. Wielinga, and R. de Hoog, "CommonKADS: A Comprehensive Methodology for KBS Development," IEEE ExpertIntelligent Systems and their Applications, vol. 9, no. 6. pp. 28-37, 1994.

[8] J. Sowa, "Knowledge Representation: Logicial, Philosophical and Computational Foundations," p. 594, 2000.

[9] J. Liebowitz, "Knowledge management and its link to artificial intelligence," Expert Syst. Appl., vol. 20, no. 1, pp. 1-6, 2001.

[10] A. Preece, A. Flett, D. Sleeman, D. Curry, N. Meany, and P. Perry, "Better knowledge management through knowledge engineering," Intell. Syst. IEEE, vol. 16, no. 1, pp. 36-43, 2001.

[11] A. Maedche, B. Motik, L. Stojanovic, R. Studer, and R. Volz, "Ontologies for enterprise knowledge management," IEEE Intell. Syst., vol. 18, no. 2, pp. 26 $33,2003$. 
[12] N. Matta, J.-L. Ermine, G. Aubertin, and J. Trivin, "How to capitalize knowledge with the MASK method ?," IJCAI 2001 Work. Knowl. Manag. Organ. Memories, Seattle,washingt. USA, pp. 1-13, 2001.

[13] L. F. Lai, "A knowledge engineering approach to knowledge management," Inf. Sci. (Ny)., vol. 177, no. 19, pp. 4072-4094, Oct. 2007.

[14] A. Napoli, Handbook of Categorization in Cognitive Science. Elsevier, 2005.

[15] A. D. Gordon and A. D. Gordont, "A Review of Hierarchical Classification," Source J. R. Stat. Soc. Ser. A J. R. Stat. Soc. A, vol. 150, no. 2, pp. 119-137, 1987.

[16] C. Dnecker and E. Kolmayer, Element de psychologie cognitive pour les sciences de l'information. Villeurbanne, , 2007.

[17] P.N. Johnson-Laird, "Mental Models in Cognitive Science," Cogn. Sci., vol. 4, no. 1, pp. 71-115, 1980.

[18] H. Barbara, "The role of classification in knowledge representation and discovery," vol. 4, no. 1, pp. 22-47, 1999.

[19] J.-E. Mai and J.-E. Mai, "Classification in context: Relativity, reality, and representation," Knowl. Organ., vol. 31, no. 1, pp. 39-48, 2004.

[20] W. J. Clancey, "Knowledge acquisition for classification expert systems," Proc. 1984 Annu. Conf. ACM fifth Gener. Chall., pp. 11-14, 1984.

[21] A. Newell, "The knowledge level," Artif. Intell., vol. 18, no. 1, pp. 87-127, 1982.

[22] J. Angele, D. Fensel, D. Landes, and R. Studer, "Developing KnowledgeBased Systems with $\{$ MIKE\}," Autom. Softw. Eng., vol. 5, no. 4, pp. 389418, 1998.

[23] P., Fayyad, U., Piatetsky-Shapiro, G \& Smyth, "From data mining to knowledge discovery in databases," in Advances in Knowledge Discovery and Data Mining, vol. 17, no. 3, 1996, pp. 1-36.

[24] R. Feldman, M. Fresko, H. Hirsh, Y. Aumann, O. Liphstat, Y. Schler, and M. Rajman, "Knowledge Management: A Text Mining Approach," Proc 2nd Int Conf Pract. Asp. Knowl. Manag., vol. Basel, Swi, pp. 1-10, 1998.

[25] I. Nonaka, "The knowledge-creating company," Harv. Bus. Rev., vol. 85, no. 7-8, pp. p96-104, 2007.

[26] J.-C. Spender, "Organizational knowledge, learning and memory: three concepts in search of a theory," J. Organ. Chang. Manag., vol. 9, no. 1, pp. 63-78, 1996.

[27] X. DAI, N. Matta, and G. Ducellier, "Cooperative Knowledge Discovery in Design Projects," in Proceedings of the International Conference on Knowledge Management and Information Sharing, 2014, pp. 27-35.

[28] S. M. Bekhti and N. T. Matta, "Knowledge Representation and Retrieval in Design Project Memory,” pp. 96-102, 2009. 